\title{
HUMANITARIANISM WITHIN STATIST BOUNDARIES: A SYSTEMIC INTERPRETATION OF ART. 1F REFUGEE CONVENTION IN LIGHT OF TERRORIST CONCERNS
}

\author{
Joseph Mahon*
}

\begin{abstract}
This article explores the application of Art. 1F Refugee Convention in light of contemporary 'terrorist' concerns. With an interpretive approach that adheres strictly to the object and purpose of the Article referred to above, it advocates a revised application of International Criminal Law to the exclusion decision, while rejecting human rights-oriented or purposive approaches to the same question. This is not backward-looking or regressive, but pragmatic, recognising the systemic objectives both of the Convention and of the Article itself, and their positions in the post-Westphalian order. The best way to support refugee protection - and to exclude those undeserving of it - is to do so within the confines of the Convention itself. Departing or attempting to reform its boundaries may do more harm than good.
\end{abstract}

\section{A. INTRODUCTION}

Art. $1 \mathrm{~F}$ of the 1951 Convention Relating to the Status of Refugees (Refugee Convention; Convention; RC) provides for the disapplication of refugee protections to those with respect to whom there are serious reasons for considering they 'have committed' or 'have been guilty of' serious crimes. It is a rarely used provision. One 2017 study noted that, in the UK, Art. 1F exclusion represented just $0.1 \%$ of initial asylum decisions and $0.2 \%$ of refusals between 2008 and 2015. ${ }^{1}$ Nevertheless, it has seen steadily increasing deployment since the 1990s, triggered initially by the brutal conflicts of Yugoslavia and Rwanda, ${ }^{2}$ and later in response to the proliferation of global terrorism. ${ }^{3}$ Following these conflicts, refugee law's ability simultaneously to shelter the vulnerable and exclude the undeserving has been highlighted. ${ }^{4}$

This article explores the contemporary application of Art. 1F. Part B provides an interpretive overview of the exclusion clause following the structure provided by the 1969 Vienna

\footnotetext{
* BPTC, Lincoln's Inn (Lord Denning Scholar); LL.M., University College London; MA (Hons), Edinburgh University

${ }^{1}$ Sarah Singer, “Undesirable and Unreturnable” in the United Kingdom' (2017) 36(1) Refugee Survey Quarterly 1, 24-25.

${ }^{2}$ William O'Neill, Bonaventure Rutinwa, and Guglielmo Verdirame. 'The Great Lakes: A Survey of the Application of the Exclusion Clauses in the Central African Republic, Kenya and Tanzania' (2000) 12 International Journal of Refugee Law 136.

${ }^{3}$ Catherine Dauvergne and Asha Kaushal, 'The Growing Culture of Exclusion: Trends in Canadian Refugee Exclusions' (2011) 23 International Journal of Refugee Law 54-92; Kate Ogg, 'Separating the Persecutors from the Persecuted: A Feminist and Comparative Examination of Exclusion from the Refugee Regime' (2014) 26 International Journal of Refugee Law 83.

${ }^{4}$ Michael K Nyinah, 'Exclusion Under Article 1F: Some Reflections on Context, Principles and Practice' (2000) 2 International Journal of Refugee Law 302.
} 
Convention on the Law of Treaties (VCLT). Part C addresses the liability of refugees under Art. 1F. First, it explores liability under $1 \mathrm{~F}(\mathrm{a})$, testing that with two critiques of exclusion's inability to consider broader coercions that minimise culpability. Second, it looks at the establishment, or not, of guilt based on an individual's membership of a group. Third, it examines liability under the Principles and Purposes of the United Nations (UN Principles), noting the expansion of 'terrorism' in international law and the confusion this has created at domestic level. Part $\mathrm{C}$ concludes by recalling that Art. $1 \mathrm{~F}$ is a moral clause, imbued with contemporary Western discourse. Part D puts forward three proposals to remedy the failures identified in part $\mathrm{C}$ : a revised application of International Criminal Law (ICL), a proportionality approach, and a human rights oriented purposivism. It is argued that the best approach is a reformed application of ICL in exclusion law. Part E supports that argument with a recognition of the inherent limits of the exclusion clause: the surrogacy of refugee protection, its statism, and its role in the sovereign order. It is argued in conclusion that the humanitarian objectives of the Convention must be advanced within these boundaries. Departing or attempting to reform them may do more harm than good.

\section{B. ROLE, RELEVANCE AND INTERPRETATION OF EXCLUSION}

As an international treaty, the RC must in principle have an autonomous meaning; it is to be understood in its own context without 'taking colour' from domestic legal systems. ${ }^{5}$ Unlike many treaties, however, it does not designate a court to resolve its disputes. The UNHCR supervises the Convention, but it lacks authority to determine or define its interpretation. ${ }^{6}$ It thus falls on domestic courts to resolve Convention disputes in accordance with the rules of interpretation found in the VCLT. Article 31(1) VCLT requires that 'a treaty shall be interpreted in good faith in accordance with the ordinary meaning to be given to the terms of the treaty in their context and in the light of its object and purpose'. ${ }^{7}$

\section{Good Faith / Context}

Good faith is a limitation that guides the exercise of treaty obligations. ${ }^{8}$ The "fundamental principle of the law of treaties,' it rejects 'extensive' or 'liberal' interpretations that depart the clear meaning

\footnotetext{
${ }^{5} R v$ SSHD, Ex parte Adan, [2001] 2 AC 477 [517] per Lord Steyn; James Hathaway and Michelle Foster, The Law of Refugee Status (2nd edn, CUP 2014) 535.

${ }^{6}$ Jane McAdam, 'Interpretation of the 1951 Convention,' in Andreas Zimmerman (ed), The 1951 Convention Relating to the Status of Refugees and Its 1967 Protocol: A Commentary (OUP 2011) 79.

${ }^{7}$ Art 31(1) Vienna Convention on the Law of Treaties 1969 (VCLT).

${ }^{8}$ North Atlantic Coast Fisheries Case (GB v USA) [1910] XI RIAA 169, 188.
} 
of its terms ${ }^{9}$ and, therefore, it gives 'legal value to the expectations that States have in the actions of other States' ${ }^{10}$ It also promotes the effectiveness of a treaty and the value it seeks to uphold. ${ }^{11}$ Regarding effectiveness, the decision to supplement the 1951 Convention with a 1967 Protocol applying its provisions to post-1951 refugees is a clear mandate to interpret the text in contemporarily applicable ways. ${ }^{12}$ So too is Art. $1 \mathrm{~F}(\mathrm{a})$ 's general exhortation to international criminal instruments. For Bond, the fact that the drafters included a general reference to international crimes, rather than a specific definition from contemporary instruments, indicates an intent to keep exclusion evolutive and in line with developments in ICL. This not only ensures it remains relevant, but protects the integrity of the Convention. ${ }^{13}$ For Wennholz, the need to protect the systemic consistency of the Convention also mandates dynamic, contemporary interpretations in line with human rights law. ${ }^{14}$ Rather than stagnate, therefore, the Convention must be viewed as a 'living instrument' lest it become an anachronism. ${ }^{15}$ This 'evolutionary approach', incorporating both ICL and wider international law was endorsed during a UNHCR expert roundtable. ${ }^{16}$

The human rights orientation of the Convention illuminates the context of Art. $1 \mathrm{~F}$ and the values that a good faith interpretation must uphold. As recognised by the State Parties, it 'sets out rights, including human rights, and minimum standards of treatment that apply to persons falling within its scope'. ${ }^{17}$ Yet it can be distinguished from other HR treaties: it is labelled a convention on refugee 'status', not 'rights'; and while later human rights treaties begin with the individual,

\footnotetext{
${ }^{9}$ International Law Commission, 'Draft Articles on the Law of Treaties with Commentaries' (1966) 2 Yearbook of the International Law Commission 212, 219.

${ }^{10}$ Steven Reinhold, 'Good Faith in International Law' (2013) 2 UCLJLJ 62.

${ }^{11}$ International Law Commission (n 9) 219. On effectiveness in interpretation of Public International Law generally, see Alexander Orakhelashvili, The Interpretation of Acts and Rules in Public International Law (OUP 2008).

${ }^{12}$ Hathaway and Foster (n 5) 9-10; Protocol Relating to the Status of Refugees (adopted 31 January 1967, entered into force 4 October 1967) 606 UNTS 267 (Protocol).

${ }^{13}$ Jennifer Bond, 'Principled Exclusions: A Revised Approach to Article 1(F)(a) of the Refugee Convention' (2013) 35 Michigan Journal of International Law 29-30; Joseph Rikhof, The Criminal Refugee: The Treatment of Asylum Seekers with A Criminal Background in International and Domestic Law (Republic of Letters 2012) 55-57.

${ }^{14}$ Philipp Wennholz, 'Article 1F 1951 Convention', in Zimmerman (n 6) The 1951 Convention Relating to the Status of Refugees and Its 1967 Protocol: A Commentary (OUP 2011) 609.

${ }^{15}$ Sepet v SSHD [2003] UKHL 15.

${ }^{16}$ Erica Feller, 'Summary Conclusions: Exclusion from Refugee Status', in Erica Feller, Voller Turk, and Frances Nicholson (eds), Refugee Protection in International Law: UNHCR's Global Consultations on International Protection (CUP 2003) 480.

17 'Declaration of States Parties to the 1951 Convention and/or its 1967 Protocol relating to the Status of Refugees', UN Doc. HCR/MMSP/2001/09, 13 Dec 2001, Preamble, s.2.
} 
the Convention is more 'state-centric'. ${ }^{18}$ Where non-refoulement (NR) is absolute under Art. 3 European Convention on Human Rights (ECHR), ${ }^{19}$ for example, Art. 33(2) RC provides an exception to NR on state security grounds. Similarly, while asylum is a fundamental humanitarian principle, the RC recognises it 'may place unduly heavy burdens on certain countries' ${ }^{20}$ This recognition underpins Art. 1F.

Yet, revolving around the core principle of non-refoulement, the Convention still demonstrates a human rights orientation. This is visible in its Preamble: considering the 'fundamental rights and freedoms' of all humans, and endeavouring 'to assure refugees the widest possible exercise' of these, it aims to 'extend the scope' of refugee protection. ${ }^{21}$ Art. $1 \mathrm{~F}$ is thus embedded in the RC as an exception to a human rights treaty. It is the disapplication of the Convention's protections to an individual, notwithstanding a well-founded fear of persecution and its consequences can be profound. It follows, and has been confirmed in case law, that the human rights context of the Convention implies a narrow and restrictive interpretation of Art. $1 \mathrm{~F} .^{22}$

\section{State Practice}

While the consideration of state practice in treaty interpretation is authorised by Art. 31(3)(b) VCLT, Hathaway and Foster advocate a narrow view of its interpretive significance in refugee law. ${ }^{23}$ This is because, as Arato has pointed out, granting significant weight to state behaviour, motivated as it frequently is by self-interest, could frustrate the purpose of an IHRL convention: constraining state conduct for the protection of individuals. ${ }^{24}$ Similar arguments are made by Singer, who questions the utility of external standards in reference to the meaning of 'terrorism' in $1 F(c),{ }^{25}$ and Hart, who sees Transnational Judicial Dialogue (TJD) as a process that dilutes, not

\footnotetext{
${ }^{18}$ Guy Goodwin-Gill, 'The International Law of Refugee Protection', in Elena Fiddian-Qasmiyeh, Gil Loescher, Katy Long, and Nando Sigona (eds), The Oxford Handbook of Refugee and Forced Migration Studies (OUP 2014) 44.

${ }^{19}$ Chahal v United Kingdom, App. 22414/93 (ECHR 15 November 1996) 96. For an opposing view in relation to medical non-refoulement claims, see John Finnis, 'Absolute Rights: Some Problems Illustrated' (2016) 61(2) The American Journal of Jurisprudence 195-215.

${ }^{20}$ Preamble to Refugee Convention. Consideration of the Preamble is authorised by Article 31(2) VCLT.

${ }^{21}$ Preamble to Refugee Convention.

${ }^{22}$ Geoff Gilbert, 'Current Issues in the Application of the Exclusion Clauses', in Feller and others (n 16) Refugee Protection in International Law: UNHCR's Global Consultations on International Protection (CUP 2003) 428; Bond (n 13) 25; R (JS (Sri Lanka)) v SSHD [2010] UKSC 15 at 2; Al-Sirri v SSHD [2012] UKSC 54 at 12.

${ }^{23}$ Hathaway and Foster (n 5) 11.

${ }^{24}$ Julian Arato, 'Subsequent Practice and Evolutive Interpretation: Techniques of Treaty Interpretation over Time and Their Diverse Consequences' (2010) 9(3) The Law and Practice of International Courts and Tribunals 486-87; Hathaway and Foster (n 5) 12.

${ }^{25}$ Sarah Singer, 'Terrorism and Article 1F(c) of the Refugee Convention: Exclusion from Refugee Status in the United Kingdom' (2014) 12(5) Journal of International Criminal Justice 1087-91.
} 
enhances, protections when searching for the 'one true meaning' of the Convention. ${ }^{26}$ Indeed, suggests Hart, the overall pattern has seen courts utilising foreign judgments to legitimise decisions that disadvantage refugees. States are reluctant to extend decisions the opposite direction, fearing that they become a target for protection applications - what Holvoet has labelled 'forum shopping' ${ }^{27}$

Nevertheless, while it may be desirable from the humanitarian perspective to subjugate state practice in treaty interpretation, we must question the legitimacy of an approach that cherrypicks from the VCLT, leaving state practice with a minimal or non-existent interpretive role. As KK (Art. 1F(c), Turkey) held in 2004, failing to give effect to state practice not only ignored the VCLT, but prevented the United Nations Charter's deployment as a living instrument capable of adaptation in line with changing times. ${ }^{28}$ On balance, therefore, the argument that state practice/TJD can diminish protection standards may be best deployed as context when considering state practice, not as sanction to reject it outright. Good faith interpretation of Art. 1F, considering the human rights context and the object and purpose of the clause, ought to provide sufficient protection against a decline in protections without subverting the order of the VCLT.

\section{Travaux Preparatoires}

Art. 32(1) VCLT provides for an examination of the travaux preparatoires - the preparatory work - of a treaty as a 'supplementary means of interpretation'. 'Supplementary', however, need not entail relegation to an inferior or subordinate position in the interpretation of a treaty. ${ }^{29}$ Indeed, suggests Justice Philip Jessup, 'the historical record is valuable evidence to be taken into account in interpreting a treaty ${ }^{30}$ In Art. 1F. the drafting history suggests two aims: first, preventing those undeserving of refugee status from benefitting from, or abusing, the Convention's protections; and second, ensuring those who have committed the gravest crimes do not escape prosecution. ${ }^{31}$ The

\footnotetext{
${ }^{26}$ Naomi Hart, 'Complementary Protection and Transjudicial Dialogue: Global Best Practice or Race to the Bottom?' (2016) 28(2) International Journal of Refugee Law 172; Guy Goodwin-Gill, 'The Search for the One, True Meaning...' in Guy Goodwin-Gill and Helene Lambert (eds), The Limits of Transnational Law: Refugee Law, Policy Harmonization and Judicial Dialogue in the European Union (CUP 2010) 218.

${ }^{27}$ Hart (n 26) 190-92; Mathias Holvoet, 'Harmonizing Exclusion under the Refugee Convention by Reference to the Evidentiary Standards of International Criminal Law’ (2014) 12(5) Journal of International Criminal Justice 1039-56. ${ }^{28}$ [2004] UKIAT 00101 at [75].

29 James Hathaway, The Rights of Refugees Under International Law (CUP 2005) 59.

${ }^{30}$ South West Africa Case (Ethiopia v South Africa; Liberia v South Africa), 1966 I.C.J. 6, 325 (July 18) (Jessup, J., dissenting).

${ }^{31}$ UNHCR 'Guidelines on Application of the Exclusion Clauses: Article 1F' ('Guidelines')(Geneva 2003) s.2; Gilbert (n 22) 427-8. For a recent case that reached the same conclusions, see AH (Article 1F(b) - Algeria [2013] UKUT 00382 (IAC).
} 
former is a moral position: some acts are 'beyond the pale'; those acts are juxtaposed beside the humanitarian nature of the Convention; and, consequently, some actors do not deserve protection. ${ }^{32}$ As stated in Pushpanathan: "those who are responsible for the persecution which creates refugees should not enjoy the benefits of a convention designed to protect those refugees' ${ }^{33}$ Yet, as explored in depth in part D, the moral status of the undeserving is perceived through the lens of the host state. It is a subjective concept, beholden, or at least vulnerable, to the 'securitising' of migration - the expansion of border restrictions on discretionary policy or security grounds. ${ }^{34}$ In the heated terrorism paradigm, this subjectivity is problematic. The latter aim-excluding serious criminals - centralises the contemporary, post-World War II push towards international accountability. It is also pragmatic; states may not willingly submit to a regime requiring them to protect such individuals. ${ }^{35}$ For France, the right to exclude serious criminals was 'a prime factor in determining [the nation's] attitude towards the Convention'; for the UK, it was required 'to promote maximum adherence to the Convention'. ${ }^{36}$

More broadly, however, these dual aims point towards the systemic objectives of the exclusion clause, where the humanitarian goals of refugee protection are balanced with the need to protect its essential integrity. In its presumption that granting refugee status to serious criminals presents a risk to the viability and integrity of refugee law, ${ }^{37}$ the exclusion clause is a pragmatic recognition of the need to 'maintain the credibility of the protection system' ${ }^{38}$ It is significant, for example, that the Convention does not disbar wider humanitarian protection following exclusion. It does, however, forbid that any such protection is granted under the Convention. ${ }^{39}$ With this compulsory denial of Convention protection, Art. 1F looks beyond the interests of individual

\footnotetext{
32 UNHCR 'Guidelines' (n 31)s.2; Kaushal and Dauvergne (n 3) 86; James Hathaway, The Law of Refugee Status (CUP 1991) 214.

${ }_{33}$ Pushpanathan v Canada (Minister of Citizenship and Immigration) [1998] 1 S.C.R. 982.

34 David Cantor, Joris Van Wijk, Sarah Singer, and Maarten Bolhuis, 'The Emperor's New Clothing: National Responses to "Undesirable and Unreturnable" Aliens Under Asylum and Immigration Law' (2017) 36(1) Refugee Survey Quarterly 1-3.

${ }^{35}$ Hathaway and Foster (n 5) 525.

${ }^{36}$ For France, UN Doc. A/CONF.2/SR.24 (Jul. 17, 1951); for UK, (UN Doc. A/CONF.2/SR.29 (Jul. 19 , 1951 ), at 15.

${ }^{37}$ Hathaway and Foster (n 5) 525-6.

${ }^{38}$ Bundesrepublik Deutschland v. B and D, C-57/09 and C-101/09 [2010] ECR I-10979 ('B and D').

39 ibid [116], [119]: the EU's incorporation of $1 \mathrm{~F}$ 'does not preclude a person from applying for 'another kind of protection' outside the scope of the Directive. That other kind of protection which Member States have discretion to grant must not, however, be confused with refugee status'.
} 
states, acting instead to uphold the unity and viability of refugee law as a whole. ${ }^{40}$ It is to be applied "“scrupulously" to protect the integrity of the institution of asylum'. ${ }^{41}$

\section{Interpretive Principles}

From the above analysis, four salient principles can be drawn. First, good faith calls for the contemporary, effective application of the Convention while upholding the human rights values it espouses. It prohibits interpretations that depart the clear meaning of its terms. Acknowledging good faith as a limitation can also illustrate the need to avoid divergence among states, promoting unified interpretation. A living instrument approach that aligns, where possible, with developments in ICL and International Human Rights Law (IHRL) is therefore supported. Second, the context of Art. $1 \mathrm{~F}$ as an exception to a human rights treaty mandates a narrow interpretation of its terms. Third, state practice is relevant, but is best deployed in a contextual role. The potential for state practice to diminish protections must always be borne in mind. Fourth, and most importantly, the twin aims of the exclusion clause-denying assistance to the undeserving and ensuring serious criminals face justice - play an integral role in preserving the viability of the refugee system. This is the core purpose of Art. 1F, so the clause must only be applied to those whose admittance would threaten that system. The following part begins the substantive assessment of exclusion in practice. These principles guide the remainder of this article.

\section{COMPLICITY IN A TERRORIST AGE}

The exclusion clause utilises international law in $1 \mathrm{~F}(\mathrm{a})$ and (c) both to define the crimes it deems excludable and determine whether the applicant 'has committed' or 'has been guilty' of those crimes. Doing so, it tethers itself to internationally agreed standards and allows for evolutive interpretations of the most egregious crimes. ${ }^{42}$ As discussed earlier, it is essential to remain in step with these laws. ${ }^{43}$ This part analyses the determination of that liability and considers that in terrorist contexts. Sub-section 1 explores ICL liability under $1 F(a)$, raising two essential critiques about its application in exclusion law. Both critiques concern exclusion's failure adequately to consider refugees' mitigating factors. Sub-section 2 examines the problems and presumptions raised when an individual is a member of a notoriously violent—perhaps 'terrorist' — group. Membership is

\footnotetext{
${ }^{40}$ Hathaway and Foster (n 5) 528.

${ }^{41}$ UNHCR 'Guidelines' (n 31) s.2.

${ }^{42}$ See Bond (n 13) 14-16.

${ }^{43}$ Guy Goodwin-Gill and Jane McAdam, The Refugee in International Law (3rd edn, Clarendon 2007$) 166$.
} 
problematic and has caused fragmentation, but it also raises questions of voluntariness - questions which go to the heart of the critiques raised by both Bond and Ogg. Sub-section 3 considers liability under the Principles and Purposes of the United Nations $(1 \mathrm{~F}(\mathrm{c}))$. It notes that the international instruments used to define 'terrorism' in this context have simultaneously broadened the term and confused its implementation in $1 \mathrm{~F}(\mathrm{c})$ assessments. An international standard is suggested to remedy this. Concluding part $\mathrm{C}$, it is argued that 'terrorism' is a Western, moral imposition onto Art. 1F. It simplifies exclusion; but that simplicity benefits neither claimants nor the clause itself.

\section{Liability Under ICL}

For Rikhof, 1F(a)'s heavy reliance on ICL has been consistent and useful when defining its crimes. ${ }^{44}$ Thus, documents such as the Rome Statute, the statutes establishing the International Criminal Tribunals for the former Yugoslavia and Rwanda (ICTY/R), and the jurisprudence of international courts have been utilised with clarity when interpreting the meaning of international crimes. ${ }^{45}$ Despite the gravity of $1 \mathrm{~F}(\mathrm{a})$ 's crimes, however, it is rare for exclusion to concern 'big fish' criminals. That is more often the work of international criminal tribunals. ${ }^{46}$ To the contrary, the many thousands that undergo Refugee Status Determination every year are more likely to be implicated in crimes than to be the primary perpetrators. They are thus more likely to be found culpable under broader principles such as complicity, or to be those to whom defences might reasonably apply. Yet, while ICL has been useful for defining crimes, the same cannot be said for 'the complete transformation of the principles of international criminal law in the area of extended liability'. ${ }^{47}$ This section considers two critiques that chime with this assertion.

a) Problem 1: Incomplete transpositions of ICL

Bond's primary concern is the failure to translate criminal law's mitigation stage into the exclusion assessment. ${ }^{48}$ Criminal proceedings have a foundational principle that the allocation of a penalty to a criminal (the sanction stage) only occurs after a preliminary determination of guilt (the culpability stage). Thus, courts can divide proceedings: guilt is determined in the culpability stage,

\footnotetext{
${ }^{44}$ Joseph Rikhof, 'Exclusion and International Law: Sui Generis or Overlap?' (2013) 20 International Journal on Minority and Group Rights 202; Rikhof, The Criminal Refugee: The Treatment of Asylum (n 13) 184.

${ }^{45}$ Rome Statute of the International Criminal Court (adopted 17 July 1998); Statute of the International Criminal Tribunal for the Former Yugoslavia (adopted 25 May 1993); Statute of the International Criminal Tribunal for Rwanda (adopted 8 November 1994). See JS (Sri Lanka) (n 22).

${ }^{46}$ William Schabas, An Introduction to the International Criminal Court (2nd ed, CUP 2014) 101.

${ }^{47}$ Rikhof, 'Exclusion and International Law' (n 44) 202; Rikhof, The Criminal Refugee: The Treatment of Asylum (n 13) 184.

48 Jennifer Bond, 'Excluding Justice: The Dangerous Intersection between Refugee Claims, Criminal Law, and ‘Guilty’ Asylum Seekers' (2012) 24(1) International Journal of Refugee Law 48.
} 
safe in the knowledge that the later sanction stage will consider what remains - the harshness of a sentence. Indeed, suggests Bond, it is the sentencing stage that so often dwells on the most ambiguous 'grey areas' of individual circumstance. Yet exclusion only includes the culpability stage, and so is blind to these ambiguities. ${ }^{49}$ This is a point echoed by other writers. Holvoet notes that the 'quasi-criminal' exclusion decision can, at times, be more serious than the criminal conviction. Yet the latter is the only one that can be tempered at sentencing stage ${ }^{50}$ Hathaway raises the argument for a 'third step' before exclusion is finalised. This recognises that prosecutorial discretion and sentencing flexibility allow ICL both to decide who to prosecute and then to mitigate findings of guilt in compelling circumstances. No such discretion or flexibility exists in exclusion. Because $1 \mathrm{~F}(\mathrm{a})$ tethers itself to ICL, it may follow that one who would benefit from that discretion in a criminal assessment ought to benefit comparably from exclusion. ${ }^{51}$

The structural discrepancies between International Refugee Law (IRL) and ICL go further, however. Though ICL has generally crystallised around high-level actors, it has also recognised a hierarchy of participation applying to low-level actors or accomplices. ${ }^{52}$ This hierarchy carries material weight at sentencing stage, where research shows supporting actors consistently receiving lesser sentences than primary ones. ${ }^{53}$ In exclusion, however, most commonly concerning low-level actors, that hierarchy is absent: with no sentencing, the refugee cannot benefit from a reduced punishment. ${ }^{54}$ They are excluded, regardless. This is well illustrated through aiding and abetting, an extended liability principle, and duress, a defence. Aiding and abetting has been recognised by the ICTY as a 'lower form of liability' where the 'form and degree of participation' must be considered at sentencing. ${ }^{55}$ Duress is more controversial in ICL, but even the dissenting judges in Erdemovic - where the majority recognised duress - agreed that it should be considered as mitigation while sentencing. ${ }^{56}$ Thus, although disagreement remains over the relevance of these issues in culpability, their role in sentencing is widely recognised. ${ }^{57}$ Yet exclusion, drawing solely

\footnotetext{
49 ibid; Bond (n 13) 35.

${ }^{50}$ Holvoet (n 27) 1055.

${ }^{51}$ Hathaway and Foster (n 5) 573.

${ }^{52}$ See generally Elies Van Sliedregt, Individual Criminal Responsibility in International Law (OUP 2012).

${ }_{53}$ Barbora Hola, Alette Smeulers and Catrien Bijleveld, 'International Sentencing Facts and Figures: Sentencing Practice at the ICTY and ICTR' (2011) 9(2) Journal of International Criminal Justice 411-39.

${ }^{54}$ Bond (n 13) 35-38.

55 Prosecutor v Mrksic, IT-95-13/1-A, 5 May 2009, s.407.

${ }^{56}$ Prosecutor v Erdemovic, IT-96-22, Separate and Dissenting Opinion of Judge Li, para 12; Separate and Dissenting Opinion of Judge Cassese, para 12; Separate and Dissenting Opinion of Judge Stephen, para 68.

${ }^{57}$ Bond (n 48) 55.
} 
on culpability frameworks, cannot consider these factors. For Bond, this ineptitude undermines the equity of Art. 1F, particularly given the morally, factually and legally complex environments Rwanda, Yugoslavia, Syria - from which contemporary refugees flee. ${ }^{58}$ These concerns are particularly prescient in the context of modern 'terrorist' groups.

\section{b) Problem 2: ICL's Innate Inadequacies}

Ogg also recognises exclusion's failures in extended liability and defences, but suggests the fault lies in the substance of ICL, not in its transposition onto exclusion law. Comparing UK jurisprudence, which has regular recourse to ICL, with that of the United States of America (US), which does not, Ogg argues that both approaches mask the coercions and pressures that drive women to commit excludable crimes. They provide fragmented assessments of the circumstances surrounding exclusion decisions and struggle to determine whether the refugee possessed a 'moral choice' in their actions. ${ }^{59}$ The US operates a strict liability persecutor bar, ${ }^{60}$ the failings of which can be illustrated through Asfaw v Gonzales. ${ }^{61}$ After two weeks of brutal torture, Asfaw, an 18year-old girl, agreed to transcribe the statements of the political prisoners her captors were detaining. In exchange, her torture would stop. In the US, she was excluded at first instance; her assistance met the threshold of the persecutor bar. Her appeal also failed; with a strict liability persecutor bar, she had no framework under which to argue that her experience and fear of torture impacted on her culpability. ${ }^{62}$ Yet, while it may be argued that ICL principles such as duress could provide such a framework, two cases from the UK-SK (Zimbabwe $)^{63}$ and $M T$ (Zimbabwe $)^{64}$ undermine that. In both cases, mens rea, duress and criminal responsibility proved too narrow to provide a holistic assessment of the applicant's circumstances. ${ }^{65} \mathrm{SK}$ was excluded under $1 \mathrm{~F}(\mathrm{a})$. As a widowed member of the Zimbabwean youth militia, she was physically and sexually abused. She wanted to leave, but deserters were beaten or killed. With the militia, she was forced to attend two farm invasions against her will and fearful of the repercussions. Her involvement amounted to crimes against humanity. ${ }^{66} \mathrm{MT}$ was a female police officer in Zimbabwe when she was instructed,

\footnotetext{
58 ibid.

${ }^{59}$ Ogg (n 3) 82-111.

${ }^{60}$ Immigration Nationality and Asylum Act 1952 (USA), s 208(b)(2)(A)(i).

${ }^{61}$ Asfaw v Gonzales 180 Fed Appx 243 (2d Cir 2006).

${ }^{62} \mathrm{Ogg}$ (n 3) 92.

${ }^{63}$ SK (Zimbabwe) v SSHD [2012] EWCA Civ 807.

${ }^{64}$ MT (Article $1 F(a)$ - aiding and abetting) Zimbabwe v. SSHD [2012] UKUT 00015 (IAC).

${ }^{65} \mathrm{Ogg}$ (n 3) 93.

${ }^{66} S K$ (n 63) ss.12-24.
} 
against her will, to harass opposition party members. In one interrogation, she slapped a detained member of the opposition. She had avoided this duty numerous times, but when her party suspected her, she participated. Failure to do so could have meant imprisonment and torture for herself. ${ }^{67}$ She was deemed complicit in crimes against humanity.

SK's mens rea was established according to Art. 30 Rome Statute: she meant to engage in the farm invasions, in full knowledge of the crime. ${ }^{6}$ Yet, for Ogg, this simplistic assessment reveals the truncating effect this mens rea standard has on an applicant's evidence. In contravention of UNHCR's call for a 'full assessment of the individual circumstances, ${ }^{69}$ the focus is narrowly confined to the acts themselves without regard for the applicant's broader motivations or fears. Neither the sexual violence, gendered power dynamics of the militia, nor even SK's (in)ability to disengage could be considered. The analysis was confined to the farm invasions, 'as is the commonplace in the criminal law' ${ }^{70}$ For Ogg, this distinction between motivation and intent, and its blindness to wider context when considering voluntariness, exemplifies the dangers in relying purely on criminal principles in exclusion assessments. ${ }^{71} \mathrm{MT}$ 's culpability was as an aider and abettor: she was deemed to have materially contributed, knowing her acts were assisting the principal's crime. ${ }^{72}$ Again, however, the restricted lens of criminal law shines through. MT knew her police force were prone to beating the opposition in custody. But it was precisely that knowledge that made her fear she would suffer the same treatment if she objected. ICL, for Ogg, is (and was) insensitive to that nuance. ${ }^{73}$ With neither applicant satisfying the imminence requirement of 31(d) Rome Statute, duress was rejected in both cases. They could not demonstrate 'a threat of imminent death or of continuing or imminent serious bodily harm'. ${ }^{74}$ For Ogg, however, the strictness of these tests leads to 'neglect [of] the gendered power imbalances between the coerced and coercer'. ${ }^{75}$ Not necessarily an imminent threat, analysis increasingly suggests that women committing war crimes or crimes against humanity do so in the shadow of sustained

${ }^{67} M T$ (n 64) ss.8-21.

${ }^{68} S K$ (n 63) ss.35-36.

${ }^{69}$ UNHCR, Guidelines, s.2.

${ }^{70} \mathrm{SK}$ (n 63) s.23; Ogg (n 3) 96.

${ }^{71} \mathrm{Ogg}(\mathrm{n} 3) 96$.

${ }^{72} M T$ (n 64) ss.129-31; Ogg (n 3) 99.

${ }^{73} \mathrm{Ogg}$ (n 3) 99.

${ }^{74}$ Article 31(d) Rome Statute (emphasis added).

${ }^{75}$ Ogg (n 3) 97. See also Deborah Post, 'Outsider Jurisprudence and the Unthinkable Tale: Spousal Abuse and the Doctrine of Duress’ (2003) 26 University of Hawaii Law Review 469-87. 
coercion. ${ }^{76}$ The threat does not rise and fall with immanence; it is constant. So, while organisations such as the UNHCR may advocate for the inclusion of duress in exclusion (using the same imminence test as the Rome Statute) ${ }^{77}$ the framework provided by ICL is itself inadequate. Though this temporal requirement is entrenched in the Rome Statute, it is essential, argues Bond, that its application is guided by a more contextualised assessment, including, for example, the individual's ability to escape. ${ }^{78}$ An examination of the membership problem considers these issues further.

\footnotetext{
${ }^{76}$ Erin Baines, 'Gender, Responsibility and the Grey Zone: Considerations for Transitional Justice' [2011] 10 Journal of Human Rights 477-93; Nicole Hogg, 'Women's Participation in the Rwandan Genocide: Mothers or Monsters?' (2010) 92 International Review of the Red Cross 69-102.

${ }^{77}$ UNHCR, Background Note on the Application of the Exclusion Clauses: Article $1 F$ of the 1951 Convention relating to the Status of Refugees (4 September 2003) $\leq \mathrm{https://www.refworld.org/docid/3f5857d24.html>} \mathrm{accessed} 8$ October 2019('Background Note') ss.69-70.

${ }^{78}$ Bond (n 13) 48-49.
} 


\section{Membership and Voluntariness}

The membership question addresses whether and to what extent complicity in excludable crimes can be inferred from an individual's membership of a group committing those crimes. It is relevant because, as discussed, most potentially excludable refugees come under the extended liability principles it centres on. Thus, a number of the concerns raised above apply. The UNHCR position is that membership alone must not be sufficient to establish liability. This has been supported by the $C J E U^{79}$ and by courts in the UK, Germany and Belgium. ${ }^{80}$ Indeed, in the seminal JS (Sri Lanka) case, the key question was 'what more than membership of an organisation is required to meet the responsibility threshold in $1 \mathrm{~F}(\mathrm{a}) ?^{9}{ }^{81}$ Yet, while membership alone is insufficient to establish liability, a position has developed whereby voluntary membership in a notoriously violent group can give rise to a rebuttable presumption of knowing participation or of acquiescence in the crimes, and thus personal responsibility. This is the stance advocated by the UNHCR and followed by courts in Holland and Canada. ${ }^{82}$ In the UK, this presumption was initially confirmed by Gurung, but later rejected by $J S$ : the nature of the group should be just one of seven factors assessed. ${ }^{83}$ At the crux of the presumption is imputed knowledge into the mind of the refugee. Yet it has been suggested, in these instances, that 'it is not the nature of the claimant's crimes which leads to exclusion, but the nature of the crimes alleged against the organization' ${ }^{84}$ If correct, this is problematic. Not only inverting the presumption of innocence, it shades into guilt by association, a position Zambelli argues has already been reached in Canada. ${ }^{85}$ Yet its main inadequacies may appear in relation not just to 'violent' groups, but to 'terrorist' ones. As Kaushal and Dauvergne found in their extensive Canadian study covering 1998 to 2008, the tendency to impute knowledge based on group membership was increasing. This was attributed to the rising prominence of 'terrorism' in exclusion discourse and judicial reasoning, and to the influence of 'post-2001 security politics'. ${ }^{86}$ Where guilt is established through imputed knowledge of a 'terrorist' group's violence, two problems stand out: first, the potential to gloss over the dualistic civil and violent

\footnotetext{
${ }^{79} B$ and $D$ (n 38) s.99.

${ }^{80}$ Rikhof, 'Exclusion and International Law' (n 44) 30.

${ }^{81} J S$ (Sri Lanka) (n 22) s.2 (emphasis added).

${ }^{82}$ UNHCR, Guidelines, s.18; Rikhof, 'Exclusion and International Law' (n 44) 230.

${ }^{83}$ Gurung v. SSHD [2002] UKIAT $04870 \mathrm{~s} .105$. Rejected in $J S$ (n 22) s.31. The seven factors are not considered binding, but as guidance.

${ }^{84}$ Dauvergne and Kaushal (n 3) 79.

${ }^{85}$ Pia Zambelli, 'Problematic Trends in the Analysis of State Protection and Article 1F(a) Exclusion in Canadian Refugee Law' (2011) 23(2) IJRL 252-87.

${ }^{86}$ Dauvergne and Kaushal (n 3) 81, 92.
} 
nature of modern 'terrorist' groups (a question of accurately defining the organisation); and second, the fact that it is precisely in relation to violent groups that factors mitigating voluntariness are most likely to be prominent. Both, however, are interrelated.

Kaushal and Dauvergne's study notes that numerous cases conflated the violent and nonviolent branches of organisations: "supporting "good deeds" within a terrorist organisation is providing support to the terrorists'. ${ }^{87}$ One case recognised Hamas both as a social/religious organisation and as a violent one, noting also that the social wing took $95 \%$ of Hamas' overall budget. Yet, the applicant's actions - attending lectures and recruiting Palestinian youths — and his shared goal of liberating Palestine made him complicit in a 'terrorist' organisation. Hamas ought to have garnered closer scrutiny. ${ }^{88}$ For Kaushal and Dauvergne, however, this case reveals deeprooted problems. Despite the multitude of Canadian tests to determine an organisation's nature, there are none, they suggest, that permit involvement without exclusion. None effectively separate violent and non-violent aims; this grounds complicity and even retroactively confirms the organisation's narrow, violent purpose. ${ }^{89}$ Yet this distinction is crucial given the multitudinous aims of contemporary terrorist groups and their bureaucratic, all-consuming nature. Violence may exist in a group, but it is rarely, if ever, the only means employed towards the group's aims. ${ }^{90}$ All these factors interact. An accountant in a town overrun by a notoriously violent group may be coerced into providing accountancy for that group. In the administrative role, a continuation of the individual's (perhaps sole) professional expertise, s/he undoubtedly contributes, and may even do so 'voluntarily', aware that s/he must provide for a family. Yet the violence of the group and the fear they instil in the community must be considered as an abrogation of the voluntariness of the accountant's actions. That individual has no real choice but to contribute. If there were an alternative, the 'voluntary' question may be correct; if not, as has been the case with recent 'caliphates', it is not.

Where an individual is a member of an organisation, Slye distils the key elements for complicity to: voluntariness of membership, knowledge of and sympathy for the organisation's

\footnotetext{
${ }^{87}$ IRB Case MA2-07509 (2003); Dauvergne and Kaushal (n 3 ) 83.

${ }^{88}$ IRB Case TA0-09663 (2001); Dauvergne and Kaushal (n 3$) 83$.

${ }^{89}$ Dauvergne and Kaushal (n 3) 84.

${ }^{90}$ Gerald Neuman, 'Humanitarian Law and Counterterrorist Force' (2003) 14(2) EJIL 289.
} 
objectives, and the stage at which the individual dissociated with the group. ${ }^{91}$ A truly moral and deserving refugee would not join voluntarily, would have neither knowledge nor sympathy for the organisation's purposes, and would dissociate at the earliest opportunity. Thus, the refugee that, faced with a crisis of conscience, rejects the group at the earliest opportunity is exalted the ideal applicant. Yet the irony is that such a refugee — in Canada at least_could no longer exist: either because their involvement in the group would implicate them at first instance, or because the knowledge imputed to them by virtue of the group's notorious violence would be such as to establish the requisite mens rea. ${ }^{92}$ And this says nothing for those who do not get the luxury of a crisis of conscience: those whose life and that of their family may depend on them serving in this group, even if in a mundane way; or those (perhaps women) who live under the kind of sustained sexual coercion that must abrogate any real choice. Refugees are not required to be 'morally pure or criminally blameless'. ${ }^{93}$ Nor, for that matter, can they be 'amoral robots'. ${ }^{94}$ Yet the complexity of exclusion lies in the complexity of the refugee's morality. Or at least it ought to. As long as the exclusion clause remains the site of a public diatribe over terrorism, however, and as long as terrorism remains over-utilised as 'another pathway into the character of the refugee', ${ }^{95}$ that complexity will be glossed over in favour of simplicity and legalistic presumptions. For anyone convinced that 'terrorists' are ritually abusing the refugee process, this is unproblematic. But under a Convention that protects the vulnerability of the refugee, and given the statistics the clearly delink terrorist and refugee flows, the imposition of rhetorically loaded terminology such as this should raise alarms.

\section{Liability Under Principles and Purposes of UN}

Liability under $1 \mathrm{~F}(\mathrm{c})$ is assessed in relation to the Principles and Purposes of the United Nations (UN). These are delineated in Arts. 1 and 2 UN Charter, so $1 F(c)$ must be considered in an international law context. In ascertaining these principles, therefore, courts have regular recourse to Security Council (UNSC) and General Assembly (UNGA) resolutions and documents such as the Rome Statute. Yet, in the context of contemporary terrorism, these documents, Juss argues,

\footnotetext{
91 Ronald Slye, 'Refugee Jurisprudence, Crimes against Humanity, and Customary International Law' in A. F. Bayefsky (ed.), Human Rights and Refugees, Internally Displaced Persons and Migrant Workers: Essays in Memory of Joan Fitzpatrick and Arthur Helton (Martinus Nijhoff 2006) 255.

92 Dauvergne and Kaushal (n 3) 88.

93 Patrick Francis Ward v AG [1993] 2 SCR 689, ss.84-6.

${ }^{94}$ Valere v Minister of Citizenship and Immigration [2005] FC 524, ss.22-4.

95 Dauvergne and Kaushal (n 3) 88
} 
have consistently broadened definitions of 'terrorism' and made it harder for applicants to claim asylum. ${ }^{96}$ Exploring this, a few instruments are worth considering. First, setting a worrying trend, a UNGA Declaration in 1997 explicitly connected refugees and terrorism. States were called to take 'appropriate measures...before granting refugee status, for the purpose of ensuring that the asylum-seeker has not participated in terrorist acts'. ${ }^{97}$ Following that, the UNSC followed suit. UNSC Resolution 1373, passed in the aftermath of the terrorist attacks on the US on 11 September 2001, outlined that terrorism was contrary to UN Principles and that it was for states to ensure that 'refugee status is not abused by [its] perpetrators, organizers or facilitators'. ${ }^{98}$ Lastly, UNSC Resolution 1624, quoting Art. 1F, called upon states to deny 'safe haven to any persons with respect to whom there is credible and relevant information giving serious reasons for considering that they have been guilty of [terrorist acts.] ${ }^{99}$ There has thus emerged a connection in the highest institutions of the international order between terrorism and asylum, despite no evidence - at the time or today - that refugees have ever been the perpetrators of these crimes. ${ }^{100}$ For Juss, these documents reveal the battery of international initiatives applicants for refugee status now face as they seek asylum. They indicate international law's developing slant. Their invocation in exclusion is a misguided weapon in a state's counter-insurgency weaponry. ${ }^{101}$

Yet, without actually defining terrorism, the dangers these instruments articulate are unspecified and merely potential. They give states free reign to revisit exclusion law and fuel the perception that 'asylum is somehow a terrorist's refuge'. ${ }^{102}$ It is thus worth considering how courts have utilised these instruments to develop an understanding of terrorism in exclusion. Shortly following the terrorist attacks in London on 7 July 2005, the first statutory definition of terrorism

\footnotetext{
${ }^{96}$ Satvinder Singh Juss 'Terrorism and the Exclusion of Refugee Status in the UK', (2012) 17(3) Journal of Conflict \& Security Law 465-99.

${ }^{97}$ Declaration to supplement the 1994 Declaration on Measures to Eliminate International Terrorism, annexed to General Assembly Resolution 51/210, UN Doc. A/RES/51/210, 17 Dec. 1996, s. 3.

${ }^{98}$ UN Doc. S/RES/1373, 28 Sept. 2001, ss.5, 3(g).

${ }^{99}$ UN Doc. S/RES/1624, 14 Sept. 2005, s.1(c).

${ }^{100}$ For contemporary, see U.N. Press Release, 'Refugees Victims of Terrorism, Not Its Perpetrators', UN Doc. GA/SHC/3667, Nov. 19, 2001, <http://www.un.org/News/Press/docs/2001/GASHC3667.doc.htm> accessed 1 September 2018. For recent, see Alex Nowrasteh, 'Terrorism and Immigration: A Risk Assessment', Cato Institute, No. 798, Sept. 2016 <https://object.cato.org/sites/cato.org/files/pubs/pdf/pa798_2.pdf> accessed 1 September 2018.

${ }^{101}$ Satvinder Singh Juss, 'Complicity, Exclusion, and the "Unworthy" in Refugee Law' (2012) 31(3) Refugee Survey Quarterly 3-4; Juss (n 96) 470-81.

${ }_{102}$ Monette Zard, 'Exclusion, Terrorism and the Refugee Convention' 13 Forced Migration Rev. 32, 32. See also Nyinah (n 4) 312-3; Geoff Gilbert, 'Running Scared Since 9/11: Refugees, UNHCR and the Purposive Approach to Treaty Interpretation' in James Simeon (ed.), Critical Issues in International Refugee Law: Strategies toward Interpretative Harmony (CUP 2010) 118.
} 
for the purposes of $1 \mathrm{~F}(\mathrm{c})$ was introduced. Echoing the UNSC resolutions above, S. 54 Immigration, Asylum and Nationality Act (IANA) 2006 provided that the UN Principles included 'committing, preparing or instigating terrorism' and encouraging or inducing others to do the same. ${ }^{103}$ 'Terrorism' was defined according to S.1 Terrorism Act (TA) 2000, itself a notably wide-ranging definition. ${ }^{104}$ Yet this already-confusing melange of international and domestic law was further complicated by the European Union's (EU) Qualification Directive (QD), introduced in $2006 .{ }^{105}$ This provided, at recital 22, that the UN Principles are to be understood in light of UNSC resolutions addressing terrorism. For Singer, this confusion translated into an inconsistent stream of domestic decisions. ${ }^{106}$ When Al-Sirri reached the Court of Appeal in 2009, the QD was found to qualify the application of the TA to $1 F(c)$ : the UN Principles were narrower than the TA definition, which would have to read down to remain within the scope of the QD. ${ }^{107}$ Later in 2009 , $K J$ (Sri Lanka) did not rely on any domestic or international sources of law. ${ }^{108}$ In 2010, DD (Afghanistan) focused its efforts on interpreting the domestic, TA definition. ${ }^{109}$ And, the following year, SS (Libya) endorsed the EU Common Position of 2001 to understand terrorism for the purposes of the QD. ${ }^{110}$ Lastly, when Al-Sirri reached the Supreme Court in 2012, the international meaning of terrorism was confirmed. The Court drew on a UN draft Convention on International Terrorism, UNHCR Guidance, and the CJEU's $B$ and $D$ decision. ${ }^{111}$ While this dynamic and flexible approach has affirmed a high threshold for terrorism that befits an exception to a humanitarian treaty, the array of sources utilised is confusing. They lack uniformity. And, while that may be a symptom of the intersection in $1 \mathrm{~F}(\mathrm{c})$ of three legal systems - international, EU and UK - it is vital to determine which is the correct approach, since 'in principle there can only be

\footnotetext{
${ }^{103}$ Immigration, Asylum and Nationality Act 2006, s.54.

${ }^{104}$ IANA 2006, s.54(2); $R v$ Gul [2013] UKSC 64, s.61; Singer, 'Terrorism and Article 1F(c) Refugee Convention' (n 25) 1080 .

105 Council Directive 2004/83/EC (29 April 2004), repealed by Council Directive 2011/95/EU (13 December 2011) on standards for the qualification of third-country nationals or stateless persons as beneficiaries of international protection, for a uniform status for refugees or for persons eligible for subsidiary protection, and for the content of the protection granted (the 'Qualification Directive'). Recital 22 of the 2004 Directive has become Recital 31 in the 2011 Directive.

106 Singer, 'Terrorism and Article 1F(c) of the Refugee Convention' (n 25) 1081.

${ }_{107}$ Al-Sirri v SSHD [2009] EWCA Civ 222, s.29.

${ }^{108}$ KJ (Sri Lanka) v SSHD [2009] EWCA Civ 292; Singer, 'Terrorism and Article 1F(c) Refugee Convention’ (n 25) 1081.

109 SSHD v. DD (Afghanistan) [2010] EWCA Civ 1407, s.55; Singer, 'Terrorism and Article 1F(c) Refugee Convention' (n 25) 1082.

${ }^{110}$ SS (Libya) V SSHD [2011] EWCA Civ 1547, s.24.

${ }^{111}$ Al-Sirri (n 22) ss.36-8. This affirmed UNHCR, Guidelines, s.17.
} 
one true interpretation of a treaty'. ${ }^{112}$ Singer therefore suggests that the international approach taken in Al-Sirri is correct. Yet, an international approach should necessitate an international definition of terrorism. Applying domestic or regional definitions could splinter the meaning of Art. $1 \mathrm{~F}(\mathrm{c}) .{ }^{113}$ But attempts at an international definition of terrorism have so far failed: the ICC could not reach agreement, and even if it could it would not be universally binding; a customary law definition avoids this dilemma, but one proposed by the Special Tribunal for Lebanon in 2011 was heavily criticised. ${ }^{114}$ Absent this definition, recourse to international standards will remain inherently limited. The solution Singer suggests is a guiding principle: that the activity in question 'attacks the very basis of the international community's coexistence'. ${ }^{115}$ Until an internationally binding definition is agreed upon, upholding this international standard does justice to the high threshold required by $1 \mathrm{~F} .{ }^{116}$ Amid concerns that exclusion is proliferating under the terrorism paradigm, it limits the broad and imprecise Art. $1 \mathrm{~F}(\mathrm{c})$ to the gravest cases, and to those where Art. $1 \mathrm{~F}(\mathrm{a})$ and (b) - both of which provide more concrete exclusion parameters - do not apply. ${ }^{117}$ Thus, it retains $1 \mathrm{~F}(\mathrm{c})$ as an 'exclusion of last resort'. ${ }^{118}$

\section{Western Priorities and the Unworthy}

This part first outlined the establishment of liability under $1 F(a)$ in reference to ICL. The shortfall of ICL in extended liability was illustrated by two critiques: Bond criticised the incomplete transpositions of ICL onto exclusion law, noting that exclusion is blind to ICL's mitigation processes; Ogg argued that ICL itself masks the-particularly gendered-concerns of the persecuted. The presumption surrounding membership of notoriously violent groups underscored exclusion's failings here. The presumption appears neat, but in fact ignores that the brutality of an organisation may go some way to abrogating the voluntariness of the joining process. By failing to distinguish between and among terrorist groups, it disregards the moral dilemmas each refugee

\footnotetext{
${ }^{112}$ R v SSHD, Ex P. Adan [2000] UKHL 67; Singer, 'Terrorism and Article 1F(c) Refugee Convention' (n 25$) 1087$. 113 Singer, 'Terrorism and Article 1F(c) Refugee Convention' (n 25) 1087. See also Nergis Canefe, 'The Fragmented Nature of the International Refugee Regime and its Consequences: A Comparative Analysis of the Applications of the 1951 Convention,' in James Simeon (ed.), Critical Issues in International Refugee Law: Strategies toward Interpretative Harmony (CUP 2014) 174-210.

${ }^{114}$ Ben Saul, 'The Special Tribunal for Lebanon and Terrorism as an International Crime: Reflections on the Judicial Function', in William A. Schabas, Yvonne McDermott and Niamh Hayes (eds), The Ashgate Research Companion to International Criminal Law: Critical Perspectives (Ashgate Publishing 2013) 79-99.

115 Al-Sirri (n 22) s.38; Singer, 'Terrorism and Article 1F(c) Refugee Convention' (n 25).

116 Singer, 'Terrorism and Article 1F(c) Refugee Convention' (n 25) 1091.

117 Wennholz (n 14) 610.

118 Nyinah (n 4) 310.
} 
faces. It is an unforgivable side effect of the febrile post-9/11 order and an affront to the object and purpose of the exclusion clause. Liability under $1 \mathrm{~F}(\mathrm{c})$ was then discussed. It was shown that the 'terrorism' as conceived in relation to the Principles and Purposes of the UN is broad and broadening, the effect of this is to render more applicants excludable under $1 \mathrm{~F}(\mathrm{c})$. Yet, the explicit link between terrorism and the UN Principles has also led to definitional confusion: courts have been inconsistent in the sources used to define terrorism. Inconsistency and fragmentation do not befit the humanitarian purposes of the Convention or the narrow aims of the exclusion clause. Singer's international principle was supported as a suitably high, uniform threshold for $1 \mathrm{~F}(\mathrm{c})$, absent a universal definition of terror.

To conclude, it is worth recalling the inherent morality of Art. 1F. It was because of this that France objected to the 'disturbing moral consequences' of initial suggestions that exclusion be discretionary. Israel too objected 'on moral grounds'. ${ }^{119}$ And it is for moral reasons that moral choice is a prerequisite for guilt under the exclusion clause: the individual is excluded because of the choices they make. Yet, while Art. 1F codified parameters, the assessments are made by individuals. Exclusion is thus imbued with the morality of the decision makers. The corollary of this, for Kaushal and Dauvergne, is the direct incorporation of Western morality and public discourse into exclusion jurisprudence; the political inscribed onto the individual. ${ }^{120}$ The imposition of terrorism on exclusion has the potential to broaden the application of the clause beyond its narrowly drawn purposes. For policy-makers, 'terrorism' is an appealing classification that catalyses candid analysis: here is terrorism, there is exclusion. ${ }^{121}$ But the simplicity of this analysis attests to its failure to consider each case individually. This is an injustice-to the refugee, to the standard of proof in Art. $1 \mathrm{~F}$, and to the object and purpose of the exclusion clause. It is essential that terrorism and asylum be disconnected. Terrorism is an emotive word that smudges and distorts the dispassionate calculus of exclusion. ${ }^{122}$ Yet these are ambitious aims. The following part examines more grounded proposals to address the inadequacies of exclusion.

\section{PROPOSALS AND SOLUTIONS}

\footnotetext{
${ }^{119}$ Quoted in Dauvergne and Kaushal (n 3) 87.

${ }^{120}$ Dauvergne and Kaushal (n 3) 87-88.

${ }^{121}$ Goodwin-Gill and McAdam (n 43) 184.

122 James Simeon, 'Terrorism and Asylum: Unravelling the Myths' (RLI Blog, 25 January 2018) <https://rli.blogs.sas.ac.uk/2018/01/25/terrorism-and-asylum-unravelling-the-myths/> accessed 17 July 2018.
} 
This section looks to remedy the critiques raised thus far. On the basis of 1F's clear language, a revised application of ICL is the first approach. Proportionality comes second, but is rejected on the basis that it could do harm to the integrity of the Convention. The third section considers a purposive, human-rights interpretation of Art. 1F. While this undoubtedly accords with the human rights values of the Convention, we must be careful not to burden the exclusion clause with the task of leading international law. This leads in to the final part on the inherent limits of Art. 1F.

\section{Revised Application of ICL.}

For Bond, the most appropriate way to remedy exclusion's failings is to revise the application of ICL to the clause. Four principles should guide this reorientation. First, that Art. 1F be narrowly applied, only to those whose admittance as a refugee would undermine the Convention. Second, that it be based on ICL. Third, that it be based only on settled norms of ICL. Fourth, that it accounts for the different purposes and procedures of ICL and exclusion. ${ }^{123}$ The first of these has been explored already. The second is premised on the fact that ICL has in fact been largely absent from substantive questions of individual responsibility in exclusion assessments. ${ }^{124}$ This submission is itself based on Rikhof's comprehensive research, which noted that exclusion frameworks rarely consider ICL holistically or consistently, but cherry-pick from it or refer to its 'essence'. In consequence, extended liability frameworks in IRL have developed independently of ICL, despite the explicit wording of $1 \mathrm{~F}(\mathrm{a})$ and despite some early attempts at congruence between the two bodies of law. ${ }^{125}$ For both Rikhof and Bond, therefore, these approaches fail in respect of the precise wording of $1 \mathrm{~F}(\mathrm{a}){ }^{126}$

Bond's third principle — that unsettled ICL norms must not inform exclusion—balances the plurality of ICL with the need for exclusion to evolve consistently in line with its developments. ${ }^{127}$ It does so by interpreting $1 \mathrm{~F}$ restrictively, ensuring that those 'on the contested margins of criminal liability' are not excluded and preventing the expansion of the clause beyond spheres of personal responsibility already established in ICL. ${ }^{128}$ This is an approach echoed by Hathaway and Foster, who note that 'the applicant for protection should receive the benefit of any lack of certainty

\footnotetext{
123 Bond (n 13).

124 ibid 32.

125 Rikhof, The Criminal Refugee: The Treatment of Asylum (n 13) 263.

126 Bond (n 13) 32.

127 ibid; Hathaway and Foster (n 5) 569; Wennholz (n 14) 609-10.

${ }^{128}$ Bond (n 13) 32.
} 
emerging from divergence in relevant normative standards'. ${ }^{129}$ It is further justified by the absence of mitigation in exclusion claims, the lack of prosecutorial discretion, and the lower standard of proof ('serious reasons for considering' as opposed to 'beyond reasonable doubt'), all of which indicate that individual responsibility should be less rigorously imposed in exclusion than in criminal law.

Though the standard of proof is not the subject of the present article, it interacts here with liability since it is to be examined in relation to the elements of the crime in question. The decision maker must find serious reasons for considering the individual 'has committed' or 'has been guilty of' excludable acts, both formulations demanding an examination of the principles governing those crimes. ${ }^{130}$ And, neither exclusion's lower standard than criminal law, nor that standard's unfamiliarity, justifies any relaxation of criminal law's fundamental principles with regards its gravest crimes. ${ }^{131}$ This is further authority for exclusion based on concrete norms of ICL. Perhaps most importantly, however, the 'serious reasons for considering' standard justifies an exploration in exclusion law of potential criminal defences. Bond, Hathaway and Foster are in agreement that when a head of criminal liability is 'disputed, in flux, or otherwise unclear,' a restrictive interpretation must not find a refugee liable under it. ${ }^{132}$ For the same reasons, defences must be considered. Just as the uncertainty generated by an unsettled norm of ICL ought to prevent exclusion, so must the uncertainty generated by a potential defence. Where doubt surrounds the liability of a refugee - either due to an unsettled norm or because of a possible defence - there is no reason to assume the credibility of asylum would be threatened by granting protection to that individual. ${ }^{133}$ In fact, denying that person refuge would do the real damage to the moral and practical foundations of refugee law.

\section{Proportionality}

For some authors, however, ICL remains inadequate to address the contextual factors in exclusion. Given the interaction in Art. 1F of IHRL and IHL, principles such as proportionality - fundamental to both bodies of law - might provide a suitable framework. For the UNHCR, proportionality can provide a 'useful analytical tool' and an 'important safeguard' to ensure that Art. 1F remains

\footnotetext{
${ }^{129}$ Hathaway and Foster (n 5) 570.

${ }^{130}$ Hathaway and Foster (n 5) 534.

${ }^{131}$ Ezokola v Canada (Citizenship and Immigration) 2013 SCC 40, s.102. On unfamiliarity: UNHCR, Background Note (n 77) s.38.

132 Bond (n 13) 32-34; Hathaway and Foster (n 5) 536.

${ }^{133}$ Hathaway and Foster (n 5) 537.
} 
'consistent with the overriding humanitarian object and purpose of the 1951 Convention'. It recognises that complementary human rights protections, often cited as justification for not including proportionality in exclusion, do not guarantee an effective 'safety valve' in all cases. ${ }^{134}$ In this assessment, decision makers are encouraged to weigh the gravity of the criminal act with the persecution faced if excluded. ${ }^{135}$ Thus, proportionality is not required for crimes against humanity, crimes against peace, or acts contrary to the Principles and Purposes of the UN, all of which are too heinous to be 'outweighed'. It could, however, apply to lesser war crimes and nonpolitical crimes. Within $1 \mathrm{~F}(\mathrm{~b})$, courts have also utilised proportionality to determine whether an act is 'political' - whether the methods by which the 'political' goal is advanced are targeted or indiscriminate, and whether they are in proportion to the oppression being challenged. ${ }^{136}$ Pushpanathan, for example, recognised 'balancing mechanisms' inherent in the adjectives 'serious' and 'non-political' found in Art. $1 \mathrm{~F}(\mathrm{~b}) .{ }^{137}$ It found tentative support during Art. 1F's drafting stage ${ }^{138}$ and has recent support in case law. $R$ (ABC (A Minor)(Afghanistan)) v SSHD for instance, called on ministers to examine 'the whole factual and legal matrix' of the case, including 'the likely punishment, if found guilty'. Generally, 'a sense of proportion and balance' was encouraged. ${ }^{139}$ It also has academic support. Wennholz's proportionality argument notes that a failure to consider persecution at home could lead to low-level (but theoretically excludable) criminals being returned to life-threatening persecution. Those individuals may benefit from another instrument's non-refoulement provisions, but that would not diminish the core antinomy: that the Convention, a protective instrument, has failed to protect against the most severe persecution. ${ }^{140}$ Bond's proportionality aims to remedy the incongruity between criminal and exclusion law by considering, in addition to that advocated by the UNHCR, the individual's contribution to the act and their moral blameworthiness, factors considered by criminal courts at the sentencing stage. ${ }^{141}$ Though not a replacement for long-term reform of exclusion, Bond sees her proposal as an easily implementable interim remedy. ${ }^{142}$ Immigration tribunals are more likely

\footnotetext{
${ }^{134}$ UNHCR, Background Note (n 77) ss. 76-7.

${ }^{135}$ UNHCR, Guidelines, s. 24.

${ }^{136} T$ v SSHD [1996] 2 All ER 865, at 787; Pushpanathan (n 33) s.982, para. 73; Attorney General v Tamil X [2010] NZSC 107.

${ }^{137}$ Pushpanathan (n 33) s. 73.

138 See Goodwin-Gill and McAdam (n 43) 172; Hathaway and Foster (n 5) 562.

${ }^{139} R$ (ABC (A Minor)(Afghanistan)) v SSHD [2011] EWHC 2937 (Admin) s.32.

140 Wennholz (n 14) 608-9.

141 Bond (n 13) 56-7.

142 ibid 58.
} 
to have expertise in public law principles such as proportionality than in international criminal law ones.

Lastly, Goodwin-Gill and MacAdam's approach is noteworthy. More accurately described as 'individualised determination' than proportionality, ${ }^{143}$ it invokes defences and wider context where evidence appears of significant persecution in the home state. Like Hathaway, they argue that 'serious reasons for considering' ought to ensure thorough scrutiny of any context that may affect the guilt of the defendant. Since such issues may well be considered under wider international law procedures (IHRL and extradition), they see no reason why a harmonised IRL would not consider those in proportionality. ${ }^{144}$ Bond and Goodwin-Gill's proportionality assessments, it may be argued, both of which consider mitigating factors, could extend proportionality beyond $1 \mathrm{~F}(\mathrm{~b})$. This is because the rationale of limiting proportionality to $1 \mathrm{~F}(\mathrm{~b})$ the idea that certain crimes are too grave ever to be offset by persecution at home - does not apply directly when there is a third factor in the balance: the blameworthiness of the individual. If an individual's blameworthiness is minimised, then perhaps that reduced liability can be offset by domestic persecution.

Pushpanathan was right to recognise 1F(b)'s inherent proportionality. Indeed, it is hard to conceive of the categorisation of a crime as political or non-political without proportionality. But the inherent, ex ante proportionality of crime categorisation does not imply an ex post proportionality to determine overall excludability after that crime has been categorised. As held in $B$ and $D$, a decision maker, having determined that a person's acts reach the seriousness threshold required for Arts. 12(2)(b) and (c) QD, cannot then be expected to undertake a fresh proportionality assessment of the seriousness of those same acts. ${ }^{145}$ This is because exclusion is effectively strict liability: commitment or guilt of the crimes outlined in Art. 1F demands a compulsory denial of Convention protections. A proportionality assessment that takes place after culpability has been established challenges the systemic viability of the refugee regime; though humanitarian, it has the potential to admit refugees who are undeserving under internationally-recognised standardswhose admittance would drag the system into disrepute. Given the growth in complementary NR protections under instruments such as the ECHR, it would be better for the RC to proceed along

\footnotetext{
143 Goodwin-Gill and McAdam (n 43) 180.

144 ibid 83.

${ }^{145} B$ and $D($ n 38) paras $108-9$.
} 
the interpretive lines of its plain meaning and not to pursue a textually questionable, ex post proportionality assessment. Wennholz' proportionality should be rejected; proportionality should be confined to the definition of 'political' for the purposes of $1 \mathrm{~F}(\mathrm{~b})$. If $B$ and $D$ was the 'death knell' for proportionality in $1 \mathrm{~F}(\mathrm{~b})$ and (c), ${ }^{146}$ for the reasons above it should extend to $1 \mathrm{~F}(\mathrm{a})$.

\section{Purposivism and Feminism}

There is ample authority to support the invocation of wider coercions in $1 \mathrm{~F}$ assessments. For the UNHCR, it is the 'high degree of seriousness' of $1 \mathrm{~F}$ crimes that dictates the inclusion of all relevant circumstances. $^{147}$ For the CJEU, confirming this high degree of seriousness, individual responsibility must be assessed considering, inter alia, 'any pressure to which [the applicant] was exposed; or other factors likely to have influenced his conduct'. ${ }^{148}$ In the UK, Gurung highlighted 'the availability of a moral choice'. ${ }^{149}$ Yet, for Ogg, the failure properly to apply this jurisprudence in $S K$ and $M T$ illustrates a more endemic problem in exclusion: that these cases invoke 'wider considerations' without simultaneously determining how such factors inform moral culpability. ${ }^{150}$ Nor is moral culpability defined in the Convention, though the inherent morality of exclusion suggests it ought to be. ${ }^{151}$ The impacts of this are gendered, and the good faith call to preserve the value inherent in the treaty is justification (if it were needed) to recognise these concerns and so to minimise discrimination against women. For Ogg, a purposive interpretation of Art. 1F can provide a tentative framework to address the relationship between coercion and offending. ${ }^{152}$

While Ogg avoids a precise test to determine which abuses could negate culpability her 'broad tapestry', drawing on IRL, IHRL, and criminal law, provides pointers. Where, for example, the refugee can evidence a tangible abuse of their human rights, that may negate moral culpability in some circumstances. Drawing on contemporary IHRL, the exclusion clause thus could lead international law in providing a site, for example, where gender-based violence could form at least a partial defence. ${ }^{153}$ Recognising these gender concerns would provide a more complete image of the circumstances surrounding excludable crimes. And, it would present decision makers with a

\footnotetext{
${ }^{146}$ Hathaway and Foster (n 5).

147 UNHCR, 'UNHCR Statement on Article $1 \mathrm{~F}$ of the 1951 Convention' (July 2009) <http://www.unhcr.org/4a5edac09.pdf> accessed 7 October 2019.

${ }_{148} B$ and $D(\mathrm{n} \mathrm{38)}$ paras $96-7$.

${ }^{149}$ Gurung (n 83) s.110.

${ }^{150} \mathrm{Ogg}$ (n 3) 104.

${ }^{151} \mathrm{Ogg}$ (n 3) 105.

152 Ogg (n 3) 84.

${ }^{153}$ Ogg (n 3) 110-11. On the dearth of such a defence in international law, see C Mackinnon, 'Women's September 11th: Rethinking the International Law of Conflict' (2006) 47 Harv. Int'l L.J. 22.
} 
more robust, female-oriented exclusion framework-essential as women begin to occupy more prominent roles in politics and so become more likely to be implicated in excludable acts, not only as perpetrators, but as victims. ${ }^{154}$ This purposive approach would be a departure from criminal law frameworks, but that reflects the 'divergent theoretical underpinnings of refugee law vis à vis criminal law'. ${ }^{155}$ Where criminal law decontextualizes the defendant-devoiding them of race, ethnicity, class or gender-refugee protection is premised on a definition requiring a well-founded fear of persecution specifically in reference to those characteristics. ${ }^{156}$

It is beyond this article to contemplate moral choice in criminal acts. Ogg herself does not attempt to do so. Her approach instead uses examples, such as the human rights defence, that could individually abrogate moral choice, and then to incorporate those into exclusion. ${ }^{157}$ Its human rights orientation certainly promotes the value in the Convention, but there are concerns over its legal legitimacy. In determining which international laws should assist the interpretation of Art. 1F, Rikhof follows a framework developed by the ILC. ${ }^{158}$ Under this, he suggests, both refugee law in general and exclusion law specifically ought to be viewed as lex specialis. Both are 'special regimes' with their own objects and purposes; other areas of law can aid interpretation where a special regime does not regulate a matter within its own scope (Rule 15), but generally the specialised regime will take priority over general law (Rules 5, 14). If Rikhof is correct, then Ogg has a prima facie obligation to demonstrate Art. 1F's inadequacy on its own to address the gender concerns she raises. If she can do so, she is justified in resorting to lex generalis - human rights law in general. If she cannot, she is not, and the analysis must be confined to the unique law of Art. $1 \mathrm{~F}$. The crucial question, therefore, is whether Art. $1 \mathrm{~F}$ is sufficient in itself to address Ogg's valid concerns. It is: through the reformed application of ICL that Bond, Hathaway and Foster advocate. Utilising ICL is not an affront to the ILC rules on lex specialis since 1F refers explicitly to ICL. Thus, while resorting to IHRL could provide desirable results, it is not justified so long as Art. $1 \mathrm{~F}$ can solve the problems itself, by reference to ICL. ${ }^{159}$ While it may be tempting to use

\footnotetext{
154 Alice Edwards, 'Age and Gender Dimensions in International Refugee Law' in Feller and others (n 16) 75.

${ }^{155}$ Ogg (n 3) 108.

${ }^{156} \mathrm{Ogg}$ (n 3) 109.

157 Ogg (n 3) 108-111.

${ }^{158}$ International Law Commission, Conclusions of the Work of the Study Group on the Fragmentation of International Law: Fifty-Eight Session, 1 May to 9 June and 3 July to 11 August 2006, UN Doc. A/CN.4/L.682/Add.1; Rikhof, 'Exclusion and International Law' (n 44) 202.

${ }^{159}$ For a similar argument about the applicability of IHL, not IHRL, in non-refoulement/armed-conflict cases, see: Hugo Storey, 'Armed Conflict in Asylum Law: The "War-Flaw"' (2012) 31(2) Refugee Survey Quarterly 1-32.
} 
exclusion as a site for human rights-oriented purposivism, any hopes for the exclusion clause be reined in by a recollection of its aims, purposes and limitations - especially sovereignty, as explored in the closing part. It explicitly follows, not leads, international law ${ }^{160}$ and so should not be burdened with 'updating' human rights or international law. This is one reason why both Hathaway and Bond advocate that exclusion should only incorporate established norms of ICL. If exclusion was permitted on tenuous, specious or shifting international law grounds, its ability to deliver consistent, just decisions would surely be undermined.

\section{Appraisal}

Three proposals were advanced in this part. On proportionality, it was noted that there are two locations for the assessment to take place: in the determination of whether a crime is 'non-political' or as a later, ex post consideration. The former is encouraged; the latter is rejected. A later, discretionary proportionality analysis runs counter to the compulsory nature of the exclusion clause and could do damage to the integrity of asylum. At any rate, $B$ and $D$ appears to signal the end of proportionality, at least in Europe. Proportionality is the weakest proposal. A human rights oriented, purposive approach could directly remedy the inequality in 1F, particularly around gender issues. It acknowledges the unique position of Art. 1F among at least three bodies of law and utilises that to remedy its structural defaults. And yet, it is to be treated with scepticism, based on the concept of lex specialis and the need to focus, first and foremost, on the wording of the Article. Hathaway and Bond's revised application of ICL is therefore the best option. It recognises the precise wording of the exclusion clause, calling on universal, settled principles to promote harmony and certainty. As numerous authors argue, these should be priorities in exclusion. ${ }^{161}$ Most importantly, however, if reformed, it contains the tools properly to address the critiques that proportionality and purposivism respond to. Hathaway and Foster, for instance, point out that the twin standards of Art. 1F - 'serious reasons' and 'has committed'/'has been guilty of' - provide ample leeway for the balancing of persecution, blameworthiness and gravity of crime. ${ }^{162}$ While this approach may appear at first glance a retreat from human rights, the closing part demonstrates that it is the opposite. If attempts to reform the application of ICL in exclusion fail, a legal basis will be established to revert to Ogg's arguments and the lex generalis of human rights.

\footnotetext{
${ }^{160}$ Hathaway and Foster (n 5) 572.

${ }^{161}$ Holvoet (n 27) 1040; Canefe (n 113).

162 Hathaway and Foster (n 5) 566.
} 


\section{E. THE LIMITS OF REFUGEE LAW}

Refugee law begins with an assumption that the refugee-producing state can protect its inhabitants. Only when it is unwilling or unable to do so, and where there is no alternative protection for the refugee, will receiving states assist. ${ }^{163}$ This increases the burden for the applicant, but it underscores the rationale of refugee protection as a surrogate. The Convention institutionalises this surrogacy. In practice, however, for Goodwin-Gill and McAdam, surrogacy has inverted the historic order of the Art. 1A(2) definition, where 'well-founded fear' comes first, followed only later by the government protections. No longer driven by the individual's well-founded fear of persecution, refugee protection is instead motivated by the ability of the primary or secondary states to protect that person. Surrogacy, therefore, has substituted the minor premise of the Convention - the origin state's ability to protect - for the major one - the individual as a rights holder. One practical result of the surrogate system is that individuals facing even the most severe persecution can legitimately be denied refugee status if there is unexhausted protection in their home state - as an Internally Displaced Person (IDP) in a regional refugee camp, for example. And, research suggests, the prevalence of applications denied on this basis has steadily increased since the mid-1980's. A 'heightened sensitivity' has emerged in (typically ex-colonial, Western) receiving countries towards arrivals from racially, politically or culturally 'different' countries. ${ }^{164}$ 'Compassion fatigue', adds Gilbert, has progressively closed off avenues for those fleeing even the most brutal conflicts - particularly among the global north. ${ }^{165}$ For Canefe, it is just one example of the Convention's deployment as a deterrence tool, rather than an extension of protection. ${ }^{166}$

This surrogacy model connects to the essentially Westphalian lines along which Conventional refugee protection has developed. The Convention serves two functions and mediates two sovereignties: first, operating as a 'population relief valve', it provides sanctuary to the persecuted in ways that do not violate the persecuting state's sovereignty (it does not authorise the use of force, for example); second, inverting the protective order, it facilitates the flight of victims through a mechanism that allows "the system to sustain itself without undergoing major

\footnotetext{
${ }^{163}$ Attorney General v Ward [1993] 2 SCR 689.

164 Canefe (n 113) 176-7.

165 Geoff Gilbert, 'Undesirable but Unreturnable' (2017) 15(1) JICJ 57.

${ }^{166}$ Canefe (n 113) 177; see also Zambelli (n 82).
} 
revisions as far as the legitimacy of states or their borders are concerned' ${ }^{167}$ Thus, although asylum presents an exception to sovereign border control, the refugee regime still developed in conjunction with - and supporting of - the territorial sanctity of those same borders. ${ }^{168}$ It may be argued, therefore, in light of the humanitarian failings of surrogacy, that the Convention system ought to be revised in line with contemporary, post-Westphalian conceptions of sovereignty as responsibility - the 'broader diminution in the significance of the nation-state itself in both international law and politics'. ${ }^{169}$ Tentatively, for example, this re-examination could revert the surrogacy process; rather than viewing state protection and 'well-founded fear' sequentially, the two could be approached disjunctively. The availability of protection at home would only be relevant insofar as it relates to the refugees well-founded fear; it would not be a primary, unitary consideration. ${ }^{170}$ For Wuerth, however, the conceptual transformation of sovereignty of the past half-century has in fact weakened, not strengthened the global enforcement of IHRL norms: institutionally, the UN has stagnated and been shown ineffective; conceptually, 'traditional' sovereignty is reviving; and doctrinally, notions such as R2P have become associated with the abuse of Western power, and even imperialism. Most broadly of all, human rights are violated daily. Rather than 'doubling down' on this failing enforcement architecture, Wuerth calls on the international community to redouble its efforts onto 'a core of sovereignty-protecting international legal norms' ${ }^{171}$ Such norms, if regained, could benefit international law more broadly and promote international compliance with human rights. In the context of the Refugee Convention, a treaty imbued with and cast into a statist structure, a more pragmatic approach may be to support statism, rather than diminish it.

Given that refugee law is an exception to sovereign border control, the exclusion clause is the exception to the exception. It makes sense, therefore, that states see self-interest in interpreting it as broadly as possible. Doing so is a means to reclaim control. ${ }^{172}$ This is particularly the case nowadays, where human rights protections regularly curtail the prerogative to remove refugees,

\footnotetext{
167 Canefe (n 113) 181.

${ }^{168}$ Catherine Dauvergne, Making People Illegal: What Globalization Means for Migration and Law (CUP 2008) 62; Canefe (n 113) 184.

169 Ingrid Wuerth, 'International Law in the Post-Human Rights Era' (2017) 96(2) Texas Law Review <https://texaslawreview.org/international-law-post-human-rights-era/> accessed 07 September 2019.

${ }^{170}$ Goodwin-Gill and McAdam (n 43) 11.

171 Wuerth (n 169).

172 See Dauvergne (n 168) 62-3.
} 
even the most 'undesirable' ones. ${ }^{173}$ One problem is that if, on the one hand, sovereignty is asserting control over borders, and yet, on the other hand, human rights is curtailing that sovereignty by preventing removals, states will see cause to distinguish between human rights and refugee law. ${ }^{174}$ This is a trend identified by Gilbert in the context of terrorism, who notes that broad interpretations of exclusion, formed in the long shadow of 9/11, have not corresponded with narrower interpretation on issues such as non-refoulement from international human rights bodies. ${ }^{175}$ To the contrary, multiple decisions have emphasised the opposite: that the fight against terrorism can undermine neither the rights of the individual nor the values such removals seek to protect. ${ }^{176}$ The effect of this simultaneous broadening of exclusion and strengthening of NR protections has been an increase in the category of 'undesirable but unremovable'. In Cantor et al's study, the common denominator in response to this dilemma was that state measures appear akin to the Emperor's New Clothes: 'they allow the sovereign to believe that his nakedness is covered without actually doing so'. ${ }^{177}$ They provide no long-term solutions, no alternatives, and no engagement with the concerns of the individual involved. This is directly applicable to exclusion. On the one hand, an expanded Art. 1F is a 'reclamation of control', a positive reassertion of sovereignty. On the other, and particularly given complementary rights protections for refugees, it seems puerile: a vacuous show of strength that leaves the 'undesirable' refugee in a rights-less limbo. ${ }^{178}$ Yet that show of strength is a necessary corollary of the Convention system. That power has to exist; state cooperation depends on it. And, as long as it mediates our statist system, so too does the Convention. The integrity and authority of refugee protection, in other words, relies on the national prerogative to exclude the undeserving.

\section{F. CONCLUSION}

There are pressing questions that are beyond this article to discuss. Regarding terrorism, for example, it must be emphasised that terrorist concerns are security concerns. And, though its language covers egregious crimes, Art. $1 \mathrm{~F}$ is not concerned with security - that is the domain of

\footnotetext{
${ }^{173}$ Cantor et. al. (n 34) 4.

${ }^{174}$ Dauvergne (n 168) 64.

175 Gilbert (n 102) 85-118.

176 Saadi v Italy, App. No. 37201/06, 28 February 2008, concurring opinion of Judge Myjer.

${ }^{177}$ Cantor and others (n 34) 5; for a comprehensive overview of this undesirable but unreturnable 'limbo', see Z YakutBahtiya, Exclusion Clauses of the Refugee Convention in Relation to National Immigration Legislations, European Policy and Human Rights Instruments: Article 1F versus the Non-Refoulement Principle (WolfLegal 2015) ch.4.

178 See Yakut-Bahtiya (n 177) 143.
} 
Art. 33(2). They are two 'distinct provisions serving different purposes'. ${ }^{179}$ Where Art. 1F aims to preserve the refugee regime, Art. 33(2) concerns national security. Excluding an individual on national security grounds, therefore, misapplies Art. $1 \mathrm{~F}$ and runs counter to the object and purpose of the Convention. The conflation of these two is lacking attention.

Nevertheless, this article has argued that the concerns brought to light by contemporary terrorism - the inadequacy of Art. 1F and ICL properly to consider coercions, the presumptions and blanket categorisations that tempt decision makers but run counter to the humanitarian nature of refugee protection, the creeping expansion of the definitions and instruments under which 'terrorists' can be excluded, and the moral imposition of Western political concerns onto victimsmust be remedied within the confines provided by the exclusion clause. That begins with good faith interpretation, upholding the value in the Convention and centralising exclusion's object and purpose: the preservation of the systemic viability of international refugee protection. It recognises the surrogate, statist and sovereign limits of the Convention, and it works within those boundaries to provide harmonised principles that will lead to universal application. These are the reasons why a revised ICL is supported as the most viable solution.

There are two counter-points to note. First, a statist approach has the potential to hinder refugeeoriented harmonisation. The EU, for example, has seen attempts at the communitarisation of refugee law dogged by border-protecting, security-oriented carve-outs by individual states. ${ }^{180}$ It is a fine balance between statism and harmonisation, and it is conceded that a statist approach has the potential, where diplomacy fails, to diminish the latter. Second, if the essence of pluralism is a 'less positivistic, more open and more responsive concept of law,' ${ }^{181}$ the statist approach is more monist. The primary concern with monism is that the normative, humanitarian foundations of refugee law will be left behind as regimes such as IHRL lose their influence. ${ }^{182}$ Again, this is a legitimate concern. But, the lex specialis approach advanced in part D dictates that IHRL-lex generalis - still has influence where such influence is justified. At any rate, it is argued that a more positivist, monist Art. $1 \mathrm{~F}$ is the best way to counter the divergence, selfinterest and moral dishonesty characterising exclusion in the era of 'terrorism'.

\footnotetext{
${ }^{179}$ UNHCR, 'Statement on Article 1F,' also: UNHCR 'Guidelines on International Protection No. 5'.

${ }^{180}$ Canefe (n 113) 203.

${ }^{181}$ See M Davies, 'The Ethos of Legal Pluralism' (2005) 27 Syd LR 317.

182 Canefe (n 113) 203-4.
} 